\title{
Nutritional Value and Acceptability of Sweet Biscuit Developed from Quality Protein Maize for Nutritional Security of Rural as well as Urban People
}

\author{
Pallavi Kumari* and Usha Singh \\ Department of Food and Nutrition (Community Science), \\ Dr. RPCAU, Pusa, Samastipur - 848125, Bihar, India \\ *Corresponding author
}

\begin{tabular}{l} 
K e y w o r d s \\
Bakery products, \\
QPM, Sweet \\
biscuit, Proximate \\
Composition, \\
Unit cost \\
\hline Article Info \\
\hline $\begin{array}{l}\text { Accepted: } \\
10 \text { March } 2020 \\
\text { Available Online: } \\
\text { 10 April } 2020\end{array}$ \\
\hline
\end{tabular}

\section{A B S T R A C T}

The sweet biscuit developed from Quality Protein Maize (QPM) was analysed for its organoleptic quality, nutritional composition and unit cost. For evaluating acceptability of sweet biscuit developed from QPM organoleptic quality was carried out. The score for appearance and overall acceptability was observed to be $8.66 \pm 0.47$ whereas it was $8.60 \pm 0.62$ for colour, $8.70 \pm 0.53$ for flavour and 8.50 \pm 0.68 for taste and $8.56 \pm 0.62$ for texture. The moisture content of sweet biscuit was $3.80 \pm 0.01$ per cent, ash content of the product was $1.35 \pm 0.01$ per cent. The percentage of fat, fibre, protein and carbohydrate was $5.26 \pm 0.02,0.90 \pm 0.03$, $2.39 \pm 0.05$ and $86.30 \pm 0.08$ respectively. Calcium and iron content of sweet biscuit was found to be $5.01 \pm 1.00$, and $1.02 \pm 0.03 \mathrm{mg}$ per $100 \mathrm{~g}$ of the product. The Sugar and starch content of product shows the availability of carbohydrate. The Sugar content sweet biscuit was $4.63 \pm 0.20$ and the starch content was 63.86 \pm 0.20 per cent. The calorific contribution of sweet biscuit was $9.56 \mathrm{Kcal}$ from protein, $47.34 \mathrm{Kcal}$ from fat and $345.20 \mathrm{Kcal}$ from carbohydrate and the total energy calculated was $402.10 \mathrm{Kcal}$. The unit cost of the product was calculated as per $100 \mathrm{~g}$ and found to be Rs 9 which was cheap as compared to the market price.

\section{Introduction}

Nutrition is the most important basic need, being a major determinant of health, labour, productivity and mental development. The nutritional well-being and health of all people are vital prerequisites for the development of societies. However, malnutrition still remains a widespread problem, and is particularly severe in developing countries with low per capita income. Bakery products are commercially prepared foods designed for ease of consumption. In rural as well as in urban areas people of all ages are affectionate of different bakery products, because of their taste, colour and easy to digest nature. 
Bakery products are popular in all over world and the production has risen by many folds due to their low cost, varied taste and textured profiles with attractive package and longer shelf-life to suit easy marketing (Patel and Rao, 1996). With increasing urbanisation, the demand of processed foods, bakery products particularly biscuits command wide popularity in rural areas as well as urban areas among all age groups.

Mostly cereal based biscuits are either poor source of protein or contain protein of poor nutritional quality. The quality of protein in such products could be improved through blending of cereal component with other nutricereals. Besides protein quality, another important factor is 'biological value', which refers to the amount of absorbed nitrogen needed to provide the necessary amino acids for different metabolic functions.

The biological value of normal maize protein is $45 \%$, while that of QPM is $80 \%$. The major part of maize as human food is being consumed as roti from flour which is prepared by grinding raw/roasted maize.

Their uses in agriculture includes as a litter for poultry and as soil conditioner. It is also used as breakfast food like corn flakes and pop corn. Recently developed alkali processing method of maize grains are gaining popularity due to better digestibility and palatability. In rural as well as in urban areas, people of all ages often take tea and biscuit as morning meal.

The traditional biscuits made up of refined flour are of low nutritional value. The biscuit developed from QPM provides better nutritional quality at no additional cost. So, the baked products, after addition QPM flour can be used in various nutritional programmes for the improvement in nutritional status. Therefore, the investigation was undertaken to develop the Sweet Biscuit from QPM and to evaluate acceptability, nutritional quality and unit cost of the product.

\section{Materials and Methods}

\section{Procurement and processing of raw materials}

QPM grains were procured in one lot from the farmer of Bhagwatpur village of Samastipur district who has cultivating the grains under close supervision of maize scientists of Dr. RPCAU, Pusa. Other food ingredients such as refined flour, refined oil, vanaspati, sugar, salt, milk powder, yeast, baking powder, vanilla powder etc. were procured from local market in one lot.

The QPM grains had undergone different processing operations such as cleaning, washing, then the QPM grains were soaked for 5 minutes in double amount of $1 \%$ lime water by weight and then heat treatment was given for 30 minutes at $85^{\circ} \mathrm{C}$ and left overnight.

Next day, the grains were washed for 4 times very carefully so that lime and bran of grains would be removed. Grains were then dried in sunlight by spreading them on a clean cloth after that grinding, sieving and packaging were done.

\section{Development of sweet biscuit from quality protein maize}

The sweet biscuit was developed from refined flour and QPM flour and in different proportion such as 90:10, 80:20, 70:30, 60:40 and 50:50. Based on the making of shape size and overall acceptability for the product, the ratio selected for the preparation of sweet biscuit was 70:30. At first refined flour and QPM flour were mixed properly by continuous sieving in required amount. 
The ingredients like refined oil, vanaspati, sugar powder, baking powder, vanilla powder, saltu, milk powder, salt and water were kept together in a utensil and mixed properly with the help of palm till the ingredients become light. Now the value added flour was added to it and smooth dough was made into ball and flattened with the help of roller. The rolled dough was cut into desired shapes by using biscuit shapener and baked at $160^{\circ} \mathrm{C}$ for 15 minutes.

\section{Determination of nutritional composition}

Moisture content was determined by Hot Air Oven method of AOAC (1975). The ash, fat and crude fibre content were analysed by using the standard procedure and techniques followed by AOAC (1975). The crude protein content was analysed by micro-kjeldhal method (NIN, 1983).

Total carbohydrate was obtained by subtracting the sum of moisture, ash, fat, crude fibre and crude protein from 100. Sugar and starch content were estimated by the method of Mahadevan and Sridhar (1986) using anthrone reagent (10- keto, 9, 10dihydroanthracine). The calcium content was determined by Titrimetric method and the iron content was determined by Wong's method.

\section{Statistical analysis}

The nutritional analysis were statistically analysed for mean and standard deviation.

\section{Results and Discussion}

For quality evaluation of sweet biscuit organoleptic quality was carried out (Table 1). The score for appearance and overall acceptability was observed to be 8.66 whereas it was 8.60 for colour, 8.70 for flavour and 8.50 for texture. The moisture content of sweet biscuit was $3.80 \pm 0.01$ per cent, ash content of the product was $1.35 \pm 0.01$ per cent.

The percentage of Fat, fibre, protein and carbohydrate was $5.26 \pm 0.02,0.90 \pm 0.03$, $2.39 \pm 0.05$ and $86.30 \pm 0.08$ respectively (Table 2). Calcium and iron content of sweet biscuit was found to be $5.01 \pm 1.00$, and 1.02 $\pm 0.03 \mathrm{mg}$ per $100 \mathrm{~g}$ of product (Table 3 ). The Sugar and starch content of product shows the availability of carbohydrate. The Sugar content sweet biscuit was $4.63 \pm 0.20$ and the starch content was $63.86 \pm 0.20$ per cent (Table 4). The calorific contribution of sweet biscuit was $9.56 \mathrm{Kcal}$ from protein, 47.34 Kcal from fat and $345.20 \mathrm{Kcal}$ from carbohydrate and the total energy calculated was $402.10 \mathrm{Kcal}$ (Table 5).

Table.1 Organoleptic quality of sweet biscuit

\begin{tabular}{|l|l|}
\hline Sensory Characteristics & Scores \\
\hline Appearance & $8.66 \pm 0.47$ \\
\hline Colour & $8.60 \pm 0.62$ \\
\hline Flavor & $8.70 \pm 0.53$ \\
\hline Taste & $8.50 \pm 0.68$ \\
\hline Texture & $8.56 \pm 0.62$ \\
\hline Overall acceptability & $8.66 \pm 0.47$ \\
\hline \multicolumn{2}{|c|}{ Mean \pm S.D. } \\
\hline
\end{tabular}


Table.2 Nutritional composition (g/100g) of sweet biscuit

\begin{tabular}{|l|l|}
\hline Parameters & g/100g \\
\hline Moisture & $3.80 \pm 0.01$ \\
\hline Ash & $1.35 \pm 0.01$ \\
Fat & $5.26 \pm 0.02$ \\
\hline Fibre & $0.90 \pm 0.03$ \\
\hline Protein & $2.39 \pm 0.05$ \\
\hline Total carbohydrate & $86.30 \pm 0.08$ \\
\hline
\end{tabular}

Mean \pm S.D.

Table.3 Calcium and Iron content of sweet biscuit

\begin{tabular}{|l|l|}
\hline Parameters & $\mathbf{m g} / \mathbf{1 0 0 g}$ \\
\hline Calcium & $5.01 \pm 1.00$ \\
\hline Iron & $1.02 \pm 0.03$ \\
\hline \multicolumn{2}{|c|}{ Mean \pm S.D. }
\end{tabular}

Table.4 Sugar and starch content of sweet biscuit

\begin{tabular}{|l|l|}
\hline Parameters & g/100g \\
\hline Sugar & $4.63 \pm 0.20$ \\
\hline Starch & $63.86 \pm 0.20$ \\
\hline \multicolumn{2}{|r}{ Mean \pm S.D. }
\end{tabular}

Table.5 Calorific contribution of nutrients of sweet biscuit

\begin{tabular}{|l|c|}
\hline \multirow{2}{*}{ Nutrients } & Calorific contribution of energy yielding nutrients \\
\cline { 2 - 2 } & Kcal/100g \\
\hline Protein (Kcal) & 9.56 \\
\hline Fat (Kcal) & 47.34 \\
\hline Carbohydrates (Kcal) & 345.20 \\
\hline Total energy (Kcal) & 402.1 \\
\hline
\end{tabular}

\section{Unit cost of the product}

The unit cost of QPM sweet biscuit was calculated by the total expenditure on material and operational cost which involved $15 \%$ of total cost. The unit cost of the product was calculated as per $100 \mathrm{~g}$ and found to be Rs 9 which was cheap as compared to the market price. So the baked products can be used in various nutritional programmes to improve the nutritional status.

\section{References}

AOAC. 1975. Official Methods of Analysis of the Association of Official Analytical Chemists. $12^{\text {th }}$ Ed. Washington D.C.

Jhonson, M.L. and Curl, T. 1973. Standard method of biochemical analysis, Kalyani Publishers, New Delhi, pp. 6265.

Mahadevan and Sridhar, R. 1986. Methods in physiological pathology. Shirakami 
publication, Madras. pp.146-147.

Maize Production Technologies, march 2011. Directorate of Maize Research (ICAR).

National Institute of Nutrition. 1983. A manual of Laboratory Techniques. Indian Council of Medical Research, Hyderabad. pp 20.

Patel, M.M. and Rao, V.G. 1996. Influence of untreated, heat treated and germinated black gram flours on biscuit making quality of wheat flour. J. Food Sci. Technol. 33(1): 53-56.

Patel, M.M. 1992. Studies on the effect of blackgram (Phaseolus mungo) on rheological and baking characteristics of wheat flour. Ph. D. Thesis, University of Mysore. Mysore, India.

Shankaran, G. 2000. Role of moisture, temperature and humidity during storage of Food grains. Third international Food convention. 20-23 October 2000 (Eds. Gopal., G., Seth, P. and Rathore, J.S.). Central Food Technology Research Instiute. Mysore. pp.11-16.

\section{How to cite this article:}

Pallavi Kumari and Usha Singh. 2020. Nutritional Value and Acceptability of Sweet Biscuit Developed from Quality Protein Maize for Nutritional Security of Rural as well as Urban People. Int.J.Curr.Microbiol.App.Sci. 9(04): 929-933. doi: https://doi.org/10.20546/ijcmas.2020.904.111 